\title{
Effects of cadmium on total phenolic compounds and flavonoids in Euglena gracilis
}

\section{Efectos de cadmio en compuestos fenolicos totales y flavonoides de Euglena gracilis}

\author{
David Cervantes-Garcia ${ }^{1}$, Rosalba Troncoso-Rojas² , Alberto Sánchez-Estrada², Daniel González- \\ Mendoza $^{1 *}$, Federico Gutierrez-Miceli ${ }^{3}$ Carlos Ceceña-Duran ${ }^{1}$ \& Onecimo Grimaldo-Juarez ${ }^{1}$
}

${ }^{1}$ Instituto de Ciencias Agrícolas de la Universidad Autónoma de Baja California (ICA-UABC). Carretera a Delta s/n C.P. 21705, Ejido Nuevo León, Baja California, México.

${ }^{2}$ Centro de Investigación en Alimentación y Desarrollo, A.C., Dirección de Tecnología de Alimentos de Origen Vegetal, Carretera a La Victoria km. 0.6, Hermosillo, Sonora 83000, México.

${ }^{3}$ Instituto Tecnologico de Tuxtla Gutiérrez Carretera panamericana km 1080, Chiapas México.

*E mail: daniasaf@gmail.com

\begin{abstract}
In the present study the production of phenolic acids and flavonoid compounds by E. gracilis exposed to two cadmium concentrations (0.02 and $0.14 \mathrm{mM})$ was evaluated using high-performance liquid chromatography (HPLC). The results showed that $E$. gracilis exposed to $0.02 \mathrm{mM} \mathrm{Cd}^{+2}$ increased significantly the total content of phenolic compounds $(798.46$ $\pm 12.61 \mu \mathrm{g} \mathrm{GA} / \mathrm{g})$ and total flavonoids $(241.34 \pm 47.63 \mu \mathrm{g} \mathrm{QE} / \mathrm{g})$ with respect to the control $(137.34 \pm 19.80 \mu \mathrm{g} \mathrm{QE} / \mathrm{g} \mathrm{DW}$ and $549.00 \pm 8.57 \mu \mathrm{g} \mathrm{GA} / \mathrm{g}$ DW, respectively). However, no significant increase in the total content of phenolic compounds $(568.54 \pm 17.42 \mu \mathrm{g} \mathrm{GA} / \mathrm{g} \mathrm{DW})$ and total flavonoids $(141.11 \pm 9.36 \mu \mathrm{g} \mathrm{QE} / \mathrm{g} \mathrm{DW})$ were observed in E. gracilis exposed to $0.14 \mathrm{mM} \mathrm{Cd}^{+2}$. Further research is necessary to determine the specific role of flavonoids in E. gracilis exposed to high concentrations of $\mathrm{Cd}^{+2}$.
\end{abstract}

KEYwords: Heavy metals, Euglena gracilis, phenolic compounds, pollution

\section{RESUMEN}

En el presente estudio la producción de compuestos fenolicos y flavonoides producidos por E. gracilis expuesto a dos concentraciones de cadmio fue evaluado usando cromatografía liquida de alta precisión (HPLC). Los resultados mostraron que $0.02 \mathrm{mM}$ de $\mathrm{Cd}^{+2}$ incrementaba significativamente el contenido total de compuestos fenolicos $(798.46 \pm 12.61 \mu \mathrm{g}$ $\mathrm{GA} / \mathrm{g})$ y flavonoides $(241.34 \pm 47.63 \mu \mathrm{g} \mathrm{QE} / \mathrm{g})$ con respecto al control $(137.34 \pm 19.80 \mu \mathrm{g} \mathrm{QE} / \mathrm{g} \mathrm{DW}$ y $549.00 \pm 8.57 \mu \mathrm{g}$ $\mathrm{GA} / \mathrm{g}$ DW) respectivamente. Sin embargo, incrementos no significativos en el contenido de compuestos fenolicos (568.54 $\pm 17.42 \mu \mathrm{g} \mathrm{GA} / \mathrm{g}$ DW) y flavonoides totales $(141.11 \pm 9.36 \mu \mathrm{g}$ QE/g DW) fueron observados en E. gracilis expuestas a $0.14 \mathrm{mM}$ de $\mathrm{Cd}^{+2}$. Futuros estudios son necesarios para determinar la función especifica de los flavonoides en $E$. gracilis expuesto a altas concentraciones de $\mathrm{Cd}^{+2}$.

Palabras clave: metales pesados, Euglena gracilis, compuestos fenolicos, contaminación

\section{INTRODUCTION}

Cadmium is not essential for living organisms. This heavy metal may be toxic at very low concentrations and have a direct negative effect on various biochemical processes in aquatic organisms (Gonzalez-Mendoza \& Zapata-Perez 2008). The occurrence of this metal in urban aquatic ecosystems is mainly due to soil applications of commercial fertilizers, sewage sludge and industrial processes (Adams et al. 2004, Romero-Puertas et al. 2007). The presence of cadmium in the environment can cause negative effects in human health due to its high potential to enter and accumulate in the food chain (Erdoğrul \& Erbili 2007, Mishra et al. 2008). Cadmium toxicity in plants can cause inactivation of photosynthesis, formation of free radical and reactive oxygen species, which result in oxidative stress (Gonzalez-Mendoza et al. 2007, Kovacil et al. 2009). The use of microbial technology to remove specific substances, such as heavy metals, has been extensively applied to the treatment of water (Rahman et al. 2011). Euglena gracilis is a freshwater unicellular flagellate found in aquatic habitats. Due to its ecological and commercial importance, this flagellate has been extensively used in the last few decades to study the effects of heavy metals in the environment 
(Cervantes-Garcia et al. 2011, Morales-Calderon et al. 2012). Studies on cadmium uptake and accumulation have shown that chloroplasts and vacuoles of E. gracilis may play a major role in the mechanisms of cadmiumresistance. Additionally, E. gracilis has the ability to remove cadmium under anaerobic conditions, which might be advantageous for metal removal from sediments of polluted water bodies or bioreactors, where $\mathrm{O}_{2}$ concentration is particularly low (Santiago-Martinez et al. 2015).

Therefore, the studies on the biochemical mechanisms involved in cadmium accumulation and inactivation in cadmium-hyper-accumulating organisms such as E. gracilis are of great interest for bioremediation purposes (CervantesGarcia et al. 2011).

Even though the biochemical mechanisms of heavy metal tolerance or inactivation in E. gracilis have been previously studied, the influence of cadmium in the production of phenolic compounds has been scarcely evaluated. Therefore, the aim of this study is to evaluate the effects of different concentrations of cadmium in the production of phenolic compounds and flavonoids in E. gracilis.

\section{MATERIALS AND METHODS}

Culture of E. Gracilis

Cells of E. gracilis Klebs (strain Z) were cultured axenically in organic E. gracilis medium (EGM) and incubated at 28 ${ }^{\circ} \mathrm{C}$ with fluorescent white light during 14/10 h light-dark period for 5 days. Aliquots of $10^{5}$ cells $\mathrm{ml}^{-1}$ ( 5 days after previous subculture) were inoculated into $100 \mathrm{ml}$ of EGM in $250 \mathrm{ml}$ grass flasks. For cadmium toxicity assays the culture medium was supplied with two concentrations of $\mathrm{CdCl}_{2}$ (0.02 and $0.14 \mathrm{mM})$. These doses were selected according to previous studies reported by Santiago-Martinez et al. (2015) who evaluated the doses-effect of different concentration of $\mathrm{Cd}(0.02$ to $0.3 \mathrm{mM})$ in E. gracilis. Cadmium-free medium was used for the control. These experiments were carried out in triplicate. For the bioassays, static cell culture was carried out at $28 \pm 1{ }^{\circ} \mathrm{C}, 14 / 10$ light-dark cycles. After 3 days of incubation, the cultures were collected by centrifugation and washed with a metal free medium.

Then, three replicates of $100 \mathrm{mg}$ of biomass previously lyophilized were placed in a tube with $1.5 \mathrm{~mL}$ of methanol $(80 \%)$, grinded at $4{ }^{\circ} \mathrm{C}$ and centrifuged at $6000 \mathrm{~g}$ for 10 min. Samples of supernatant were taken and used in the evaluation of phenol and flavonoids' contents.

DETERMINATION OF TOTAL PHENOL CONTENT AND FLAVONOIDS The content of total phenolic compounds and flavonoids were determined by the Folin-Ciocalteau and aluminum chloride colorimetric methods (Quettier et al. 2000, NuñezRamirez et al. 2011). Total phenol values were expressed in terms of gallic acid equivalent ( $\mathrm{mg} \mathrm{g}^{-1}$ of dry mass), through the calibration curve with gallic acid, ranging from 0 to $300 \mu \mathrm{g} / \mathrm{ml}$. The content of flavonoids was calculated as quercetin from a calibration curve. The calibration curve was prepared with quercetin solutions, at concentrations from 10 to $100 \mathrm{mg} \mathrm{ml}^{-1}$ in methanol.

IDENTIFICATION OF PHENOLIC ACIDS AND FLAVONOIDS BY HPLC The extractions of phenolic acids from samples of $E$. gracilis for HPLC analysis were prepared according to Cervantes-Garcia et al. (2012). Separation of phenolic acids was carried out by gradient elution high performance liquid chromatography (GEHPLC) based in previous studies (Sanchez-Estrada et al. 2009). The HPLC system consisted of quaternary pump model 9012, equipped with an UV detector model 9050, a Prodigy 5u ODS3 100A (Phenomenex, CA, USA) column (250 mm length, $4.6 \mathrm{~mm}$ of internal diameter and $5 \mu \mathrm{m}$ particle size) with a C-18 guard column. The detector was set to $280 \mathrm{~nm}$ and flow rate to $1 \mathrm{ml} / \mathrm{min}$ (Varian Inc., Co. Palo Alto, CA, USA).

The solutions of the phenolic acid mixture were prepared with $0.01 \mathrm{~g}$ of each phenolic acid and mixed with a solution of 1:1 ammonium acetate buffer $200 \mathrm{~mm} \mathrm{pH} 5.4$ and methanol. The efficiency of the GEHPLC methodology for separation of phenolic acids and flavonoids was tested by preparing a solution containing the following commercially available standards: gallic acid, protocatechuic acid, hydroxybenzoic acid, vanillic acid, chlorogenic acid, caffeic acid, ferulic acid, p-coumaric acid, sinapic acid, o-coumaric acid, naringenin, kaempferol, quercetin, rutin, naringin and cinnamic acid (Sigma-Aldrich Chemical Co. St. Louis, MO, USA).

\section{STATISTICAL ANALYSIS}

The data are presented as mean values. Statistical analysis was carried out by one way ANOVA for repeated measures followed by Tukey's posthoc test. Differences were considered significant if $\mathrm{p} \leq 0.05$.

\section{RESULTS AND DISCUSSION}

Our result showed that the increase in the production of flavonoid and phenolic compounds by E. gracilis was not dependent on the concentration of cadmium used in the culture medium. Exposure of E. gracilis to $0.02 \mathrm{mM}$ $\mathrm{Cd}^{+2}$ increased significantly the total content of flavonoids (241.34 $\pm 47.63 \mu \mathrm{g} \mathrm{QE} / \mathrm{g} \mathrm{DW})$ and phenols $(798.46 \pm 12.91$ $\mu \mathrm{g}$ GA/g DW) with respect to control $(137.04 \pm 19.80 \mu \mathrm{g}$ $\mathrm{QE} / \mathrm{g} \mathrm{DW}$ and $549 \pm 8.57 \mu \mathrm{g} \mathrm{GA} / \mathrm{g} \mathrm{DW}$, respectively). In contrast, when E.gracilis was exposed to $0.14 \mathrm{mM} \mathrm{Cd}^{+2}$ no 
significant increases in the total flavonoids $(141.11 \pm 9.36$ $\mu \mathrm{g}$ QE/g DW) and phenolic compounds (568.54 $\pm 17.42 \mu \mathrm{g}$ GA/g DW) were observed (Table 1).

These results show that exposure of E. gracilis to low concentration of $\mathrm{Cd}^{+2}(0.02 \mathrm{mM})$ stimulated the production of phenols and flavonoids. Surprisingly, no effects were observed when E. gracilis was exposed to high concentration of $\mathrm{Cd}^{+2}(0.14 \mathrm{mM})$. The response to low concentrations of cadmium may be the result of the presence of antioxidant metabolites such as proline or glutathione in E. gracilis, which help in the reduction of stress caused by $\mathrm{Cd}^{+2}$ (Cervantes-Garcia et al. 2011). In this sense, the phenol and flavonoid may play an important role in the tolerance of $E$. gracilis at defined ranges of cadmium concentrations.

TABLE 1. Total flavonoids and phenolic contents of Euglena gracilis exposed to Cadmium.

TABLA 1. Contenidos totales de flavonoides y fenoles de Euglena gracilis expuestas a Cadmio.

\begin{tabular}{ccc}
\hline Cadmium doses $(\mathrm{mM})$ & Total phenolics contents $(\mu \mathrm{g} \mathrm{GA} / \mathrm{g} \mathrm{DW})$ & Flavonoids contents $(\mu \mathrm{g}$ QE/g DW) \\
\hline 0.0 & $549.00 \pm 8.57^{\mathrm{a}}$ & $137.34 \pm 19.80^{\mathrm{a}}$ \\
0.02 & $798.46 \pm 12.91^{\mathrm{b}}$ & $241.34 \pm 47.63^{\mathrm{b}}$ \\
0.14 & $568.54 \pm 17.42^{\mathrm{a}}$ & $141.11 \pm 9.36^{\mathrm{a}}$ \\
\hline
\end{tabular}

Values correspond to mean \pm standard error $(n=3)$. Within each column different capital letter indicate significant difference according to Tukey test $(\mathrm{p}<0.05)$

An alternative hypothesis to explain the lack of increase in phenolic and flavonoid compounds in E. gracilis exposed to $0.14 \mathrm{mM} \mathrm{Cd}^{+2}$ could be attributed to the impairment of antioxidative system responses due to the exposure to a high concentration of $\mathrm{Cd}^{+2}$, in such a way that this organism is not able to synthesize new phenolic and flavonoid compounds. Similar results has been reported in Spartina densiflora and Erica andevalensis, which are not able to counteract the effects of exposure to high concentration of $\mathrm{Cd}^{+2}$. In these cases, exposure to low concentrations of $\mathrm{Cd}^{+2}$ caused the synthesis of antioxidant metabolites, such as ascorbic acid and glutathione compounds (Márquez-Garcia et al., 2012, Dominguez-Garcia et al., 2010). The HPLC analysis showed the presence of three phenolic compounds (gallic acid, caffeic acid, and $p$-coumaric acid) when $E$. gracilis was culture $\mathrm{n}$ medium containing no $\mathrm{Cd}^{+2}$ (Fig. 1a). In contrast, presence of gallic acid and $p$-coumaric acid was observed when E. gracilis was exposed to $0.02 \mathrm{mM} \mathrm{Cd}^{+2}$ (Fig. 1b). The exposure of $E$. gracilis to high concentrations of $\mathrm{Cd}^{+2}$ $(0.14 \mathrm{mM})$ showed the presence of only gallic acid (Fig. 1c).

Analysis of flavonoid contents by HPLC showed that only naringenin was identified in $E$. gracilis exposed to $\mathrm{Cd}^{+2}(0.02$ or $0.14 \mathrm{mM}$ ) and in the control (Fig. $2 \mathrm{a}, \mathrm{b}$ and c). Tolerance of $E$. gracilis to $\mathrm{Cd}^{+2}$ is related to mechanisms that involve the synthesis of short-chain of phytochelatins, glutathione and the activity of antioxidant enzymes (Castro-Guerrero et al. 2008, Garcia-Garcia et al. 2014). However, recent studies has reported that flavonoid and phenolic compounds could act as alternative antioxidants when antioxidative enzymes and glutathione are affect by heavy metals (Kovacik et al. 2009, Sanchez-Viveros et al. 2010). Recent work from our laboratory showed that phenolic and flavonoid compounds

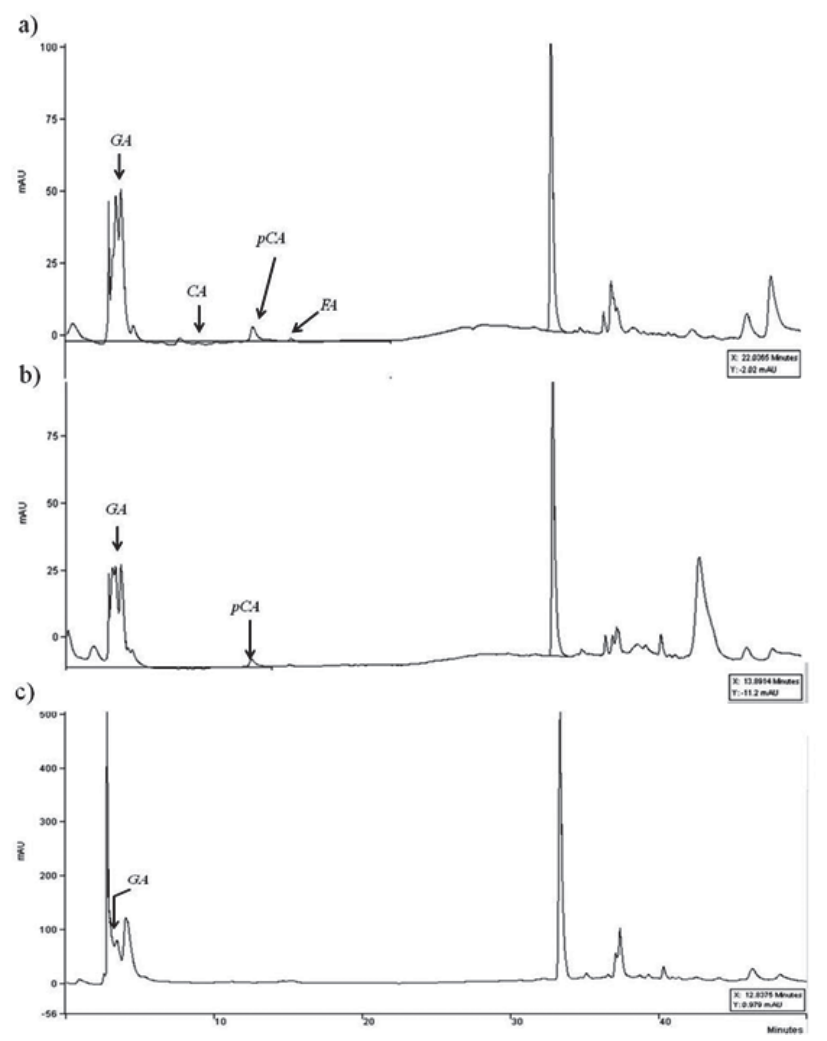

FIgURE 1. Differences in phenolic compounds of hydrolysed extracts of Euglena gracilis: (a) control, (b) and (c) exposed to 0.02 and $0.14 \mathrm{mM} \mathrm{Cd}^{+2}$, respectively. Peaks: $G A$, gallic acid; $C A$, caffeic acid; $p C A, p$-coumaric acid; $F A$, ferulic acid.

Figura 1. Diferencias en los compuestos fenólicos de extractos hidrolizados de Euglena gracilis: (a) control, (b) y (c) expuestos a 0,02 y $0,14 \mathrm{mM} \mathrm{Cd}+2$, respectivamente. Peaks: $G A$, ácido gálico; $C A$, ácido cafeico; $p C A$, ácido $p$-cumárico; $F A$, ácido felúrico. 
can act as nonenzymatic antioxidant and protect $E$. gracilis against oxidative stress when exposed to copper. However, in the present study our results suggest that production of phenolic and flavonoid compounds by E. gracilis do not represent a mechanism to $\mathrm{Cd}^{+2}$ tolerance. These results are not in agreement with previous work by Bai et al. (2004) and Dai et al. (2012) that suggest antioxidant and metal chelating properties of phenolic and flavonoid compounds in plants exposed to cadmium.
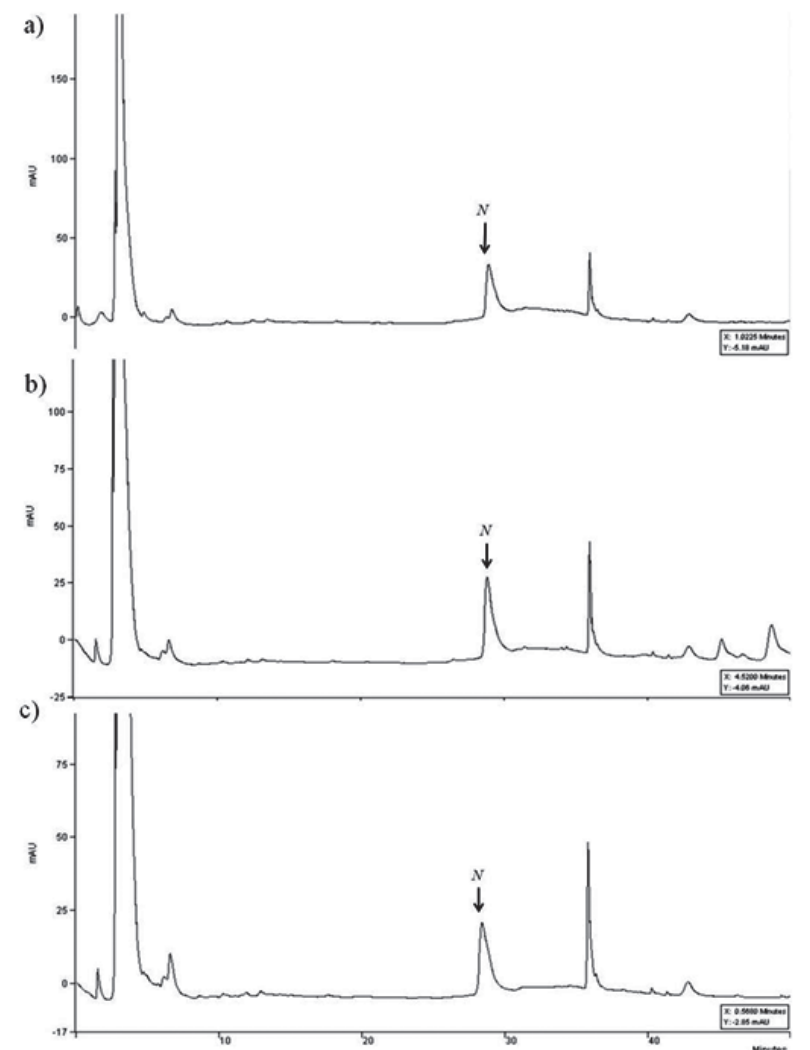

Figure 2. Differences in flavonoid compounds of hydrolysed extracts of Euglena gracilis: (a) control, (b) and (c) exposed to 0.02 and $0.14 \mathrm{mM} \mathrm{Cd}^{+2}$, respectively. Peaks: $N$, narigenin

Figura 2. Diferencias en los compuestos flavonoides de extractos hidrolizados de Euglena gracilis: (a) control, (b) y (c) expuestos a 0,02 y $0,14 \mathrm{mM} \mathrm{Cd}+2$, respectivamente. Peaks: $\mathrm{N}$, naringenina

\section{CONCLUSION}

In the present study the exposure of E. gracilis to $\mathrm{Cd}^{+2}$ showed that the production of phenolic compounds may participate in heavy metal tolerance. Further research is necessary to study the specific contribution of flavonoids in the exposure of $E$. gracilis to high concentration of $\mathrm{Cd}^{+2}$.

\section{ACKNOWLEDGMENTS}

Authors thank the Consejo Nacional de Ciencia y Tecnologia (CONACyT) de Mexico by the financial support to this work (Grant no. 079234).

\section{BIBLIOGRAPHY}

Adams, M.L., Zhao, F.J., Mcgrath, S.P., Nicholson, F.A. \& Chambers, B. 2004. Predicting cadmium concentrations in wheat and barley grain using soil properties. Journal of Environmental Quality 33:532-541.

Bai, Y., Song, F., Chen, M., Xing, J., Liu, Z. \& Liu, S. 2004. Characterization of the rutin-metal complex by electrospray ionisation tandem mass spectrometry. Analytical Sciences. 20:1147-1151.

Castro-Guerrero, N.A., Rodríguez-Zavala, J.S., MarínHernández, A., Rodríguez-Enríquez, S. \& MorenoSÁNCHEZ, R. 2008. Enhanced alternative oxidase and antioxidant enzymes under $\mathrm{Cd}^{(2+)}$ stress in Euglena. Journal of Bioenergetics and Biomembranes 40:227-235.

Cervantes-García, D., GonzÁlez-Mendoza, D., GrimaldoJuÁrez, O. \& Aviles-Marin, S. 2011. Changes on proline, phenolics compounds and antioxidants status in Euglena gracilis exposed to copper. African Journal Microbiology Research 5:5127-5131.

Cervantes-Garcia, D., Troncoso-Rojas, R., SÁnchez-Estrada, A., González-Mendoza, D. \& Grimaldo-Juarez, O. 2012. Production of Phenolics and Flavonoids Compounds in Euglena gracilis Under Copper Stress. Journal of Pure and Applied Microbiology 7:93-100.

DAI, L.P., Dong, X.J. \& MA, H.H. 2012. Antioxidative and chelating properties of anthocyanins in Azolla imbricata induced by cadmium. Polish Journal Environmental Studies 21:837-844.

Domínguez, D.M., García, F.C., Raya, A.C. \& Santiago, R.T. 2010. Cadmium-induced oxidative stress and the response of the antioxidative defense system in Spartina densiflora. Physiologia Plantarum. 139:289-302.

ERdoĞRUL, Ö. \& ERBILIR, F. 2007. Heavy metal and trace elements in various fish samples from Sir Dam Lake, Kahramanmaraş, Turkey. Environmental Monitoring and Assessment 130:373-379.

García-García, J.D., Girard, L., Hernández, G., Saavedra, E., Pardo, J.P., Rodríguez-Zavala, J.S., Encalada, R., ReyesPrieto, A., Mendoza-Cózatl, D.G. \& Moreno-Sánchez R. 2014. Zn-bis-glutathionate is the best co-substrate of the monomeric phytochelatin synthase from the photosynthetic heavy metal-hyperaccumulator Euglena gracilis. Metallomics 6:604-616.

GonzÁlez-Mendoza, D. \& Zapata Pérez, O. 2008. Mecanismos de tolerancia a elementos potencialmente tóxicos en plantas. Boletín de la Sociedad Botánica de México 82:53-61.

Gonzalez-Mendoza, D., Santamaría, J.M. \& Zapata-Perez, O. 2007. Multiple effects of cadmium on the photosynthetic apparatus of Avicennia germinans L. as probed by OJIP chlorophyll fluorescence measurements. Zeitschrift für 
Naturforschung B 62:265-272.

Kovacik, J., Klejdus, B., Hedbavny, J., Stork, F. \& Backor, M. 2009. Comparison of cadmium and copper effect on phenolic metabolism, mineral nutrients and stress-related parameters in Matricaria camomilla plants. Plant and Soil 320:231-242.

Márquez-García, B., Fernández-Recamales, M.A. \& Córdoba, F. 2012. Effects of cadmium on phenolic composition and antioxidant activities of Erica andevalensis. Journal Botany http://dx.doi.org/10.1155/2012/936950.

Mishra, V.K., Upadhyaya, A.R., Pandey, S.K. \& Tripathi, B.D. 2008. Heavy metal pollution induced due to coal mining effluent on surrounding aquatic ecosystem and its management through naturally occurring aquatic macrophytes. Bioresource Technology 99: 930-936.

Morales-Calderón, L.S., Armenta-Ortiz, N., Méndez-Trujillo, V., Ruiz-Sanchez, E., González-Mendoza, D., GrimaldoJuarez, O., Cervantes-Diaz, L. \& Aviles-Marin, M. 2012. Copper induced biofilm formation and changes on photosynthetic pigment in Euglena gracilis. African Journal Microbiology Research 6:1833-1836.

NúÑez-Ramírez, F., GonzÁlez-Mendoza, D., Grimaldo-Jú́rez, O. \& DíAz, L.C. 2011. Nitrogen fertilization effect on antioxidants compounds in fruits of habanero chili pepper (Capsicum chinense). International Journal of Agriculture \& Biology 13: 827-830

Quettier, D.C., Gressier, B., Vasseur, J., Dine, T., Brunet, C. \& LuYCKX, C. 2000. Phenolic compounds and antioxidant activities of buckwheat (F. esculentum Moench) hulls and flour. Journal Ethnopharmacology 72:35-42.
Rahman, I.M.M., Islam, M., Hossain, M., Hossain, M.S., Begum, Z.A., Chowdhury, D.A., Chakraborty, M.K., Azizur-Rahman, M., Nazimuddin, M. \& Hasegawa, H. 2011. Stagnant surface water bodies (SSWBs) as an alternative water resource for the Chittagong metropolitan area of Bangladesh: Physicochemical characterization in terms of water quality indices. Environmental Monitoring and Assessment 173:669-684.

Romero-Puertas, M.C., Corpas, F.J., Rodríguez-Serrano, M., Gómez, M., Del Río L.A. \& Sandalio, L.M. 2007. Differential expression and regulation of antioxidative enzymes by $\mathrm{Cd}$ in pea plants. Jorunal of Plant Physiology 164:1346-1357.

SÁnchez-Estrada, A., Tiznado-Hernández, M.E., OJedaContreras, A.J. \& Troncoso-Rojas, R. 2009. Induction of defense mechanism against Fusarium oxysporum in netted melon (Cucumis melo) fruit with bio-elicitor. Journal Phytopatholy 157:24-32.

SÁnchez-Viveros, G., GonzÁlez-Mendoza, D., Alarcón, A. \& Ferrera-Cerrato, R. 2010. Copper effects on photosynthetic activity and membrane leakage of Azolla filiculoides and A. caroliniana. International Journal of Agriculture \& Biology 12:365-368.

Santiago-Martínez, M.G., Lira-Silva, E., Encalada, R., Pineda, E., Gallardo-Pérez, J.C., Zepeda-Rodriguez, A., Moreno-Sánchez, R., SaAvedra, E. \& Jasso-Chávez, R. 2015. Cadmium removal by Euglena gracilis is enhanced under anaerobic growth conditions. Journal Hazardous Materials 288:104-112.

Recibido: 27.12.15

Aceptado: 09.03.16 